\title{
The spatial distribution of the reactive iodine species IO from simultaneous active and passive DOAS observations
}

\author{
K. Seitz ${ }^{1}$, J. Buxmann ${ }^{1}$, D. Pöhler ${ }^{1}$, T. Sommer ${ }^{1, *}$, J. Tschritter ${ }^{1}$, T. Neary ${ }^{2}$, C. O’Dowd ${ }^{2}$, and U. Platt ${ }^{1}$ \\ ${ }^{1}$ Institute of Environmental Physics, University of Heidelberg, Im Neuenheimer Feld 229, 69120 Heidelberg, Germany \\ ${ }^{2}$ School of Physics \& Centre for Climate \& Air Pollution Studies, Environmental Change Institute National University of \\ Ireland, Galway, University Road, Galway, Ireland \\ *now at: Eawag, Limnological Research Center, Seestr. 79, Kastanienbaum, Switzerland
}

Received: 19 August 2009 - Published in Atmos. Chem. Phys. Discuss.: 12 October 2009

Revised: 3 February 2010 - Accepted: 18 February 2010 - Published: 1 March 2010

\begin{abstract}
We present investigations of the reactive iodine species (RIS) IO, OIO and $\mathrm{I}_{2}$ in a coastal region from a field campaign simultaneously employing active long path differential optical absorption spectroscopy (LP-DOAS) as well as passive multi-axis differential optical absorption spectroscopy (MAX-DOAS). The campaign took place at the Martin Ryan Institute (MRI) in Carna, County Galway at the Irish West Coast about $6 \mathrm{~km}$ south-east of the atmospheric research station Mace Head in summer 2007. In order to study the horizontal distribution of the trace gases of interest, we established two almost parallel active LP-DOAS light paths, the shorter of $1034 \mathrm{~m}$ length just crossing the intertidal area, whereas the longer one of $3946 \mathrm{~m}$ length also crossed open water during periods of low tide. In addition we operated two passive Mini-MAX-DOAS instruments with the same viewing direction. While neither OIO nor $\mathrm{I}_{2}$ could be unambiguously identified with any of the instruments, IO could be detected with active as well as passive DOAS. The IO column densities seen at both active LP-DOAS light paths are almost the same. Thus it can be concluded that coastal IO is almost exclusively located in the intertidal area, where we detected mixing ratios of up to $29 \pm 8.8 \mathrm{ppt}$ (equivalent to $\mathrm{pmol} / \mathrm{mol}$ ). Nucleation events with particle concentrations of $10^{6} \mathrm{~cm}^{-3}$ particles were observed each day correlating with high IO mixing ratios. Therefore we feel that our detected IO concentrations confirm the results of model studies, which state that in order to explain such particle bursts, IO mixing ratios of 50 to $100 \mathrm{ppt}$ in so called "hot-spots" are required.
\end{abstract}

Correspondence to: K. Seitz (katja.seitz@iup.uni-heidelberg.de)

\section{Introduction}

It is well known that reactive halogen species (RHS) affect tropospheric chemistry in different ways. A drastic example is the total depletion of boundary layer ozone in polar spring within days or hours by catalytic cycles involving bromine (see e.g., Barrie et al., 1988; von Glasow and Crutzen, 2007; Simpson et al., 2007 and references therein). While the destruction of arctic boundary ozone appears to be mainly driven by $\mathrm{BrO}$ (with minor contributions from IO and $\mathrm{ClO}$ ), at mid latitudes (Read et al., 2008) and possibly in Antarctica (Frieß et al., 2001; Saiz-Lopez et al., 2008; Schönhardt et al., 2008) IO plays an important role in the process of ozone destruction. Besides its influence on the ozone budget, reactive iodine (like reactive bromine) affects atmospheric chemistry by changing the $\mathrm{NO} / \mathrm{NO}_{2}$ and $\mathrm{OH} / \mathrm{HO}_{2}$ partitioning (e.g., Platt and Hönninger, 2003). Additionally, recent field studies, mainly carried out at Mace Head atmospheric research station (Mace Head) (e.g., O'Dowd et al., 2002; Mäkelä et al., 2002) indicate that reactive iodine plays a key role in the formation of new particles in coastal areas. This phenomenon has been studied in several laboratory experiments (e.g., Hoffmann et al., 2001; Jimenez et al., 2003; Burkholder et al., 2004; McFiggans et al., 2004; Palmer et al., 2005) and model studies (e.g., Pechtl et al., 2006; Saiz-Lopez et al., 2006a; Vuollekoski et al., 2009). A review of the current knowledge on marine aerosol production can be found in O'Dowd and de Leeuw (2007). If those particles grow to become cloud condensation nuclei ( $\mathrm{CCN})$, they could influence cloud properties and therefore have an impact on climate.

The most likely source of reactive iodine is the photolysis of molecular iodine and organohalogens emitted by

Published by Copernicus Publications on behalf of the European Geosciences Union. 
macroalgae. While initially organohalogens, especially the short-lived diiodomethane $\mathrm{CH}_{2} \mathrm{I}_{2}$ were assumed to be the major precursors of reactive iodine (Carpenter, 2003), at the reported levels of $\mathrm{I}_{2}$ and $\mathrm{CH}_{2} \mathrm{I}_{2}$, the former would constitute the dominating source of RHS (McFiggans et al., 2004). The emission of molecular iodine from Laminaria Digitata was studied by Dixneuf et al. (2009), while Ball et al. (2009) report emission rates for different seaweed species.

Most of the measurements of RHS at coastal sites were conducted at Mace Head (e.g., Alicke et al., 1999; Hebestreit, 2001; Saiz-Lopez and Plane, 2004a; Saiz-Lopez et al., 2004a, 2006a,b; Peters et al., 2005; Bale et al., 2008), which is located about $6 \mathrm{~km}$ North-West of the MRI. However, Lee et al. (2010) and Stutz et al. (2007) report observation of reactive halogen species from the tropical Northern Atlantic and the Gulf of Maine, respectively, while Mahajan et al. (2009) and Furneaux et al. (2009) measured reactive halogen species at the French Atlantic Coast. Previous important measurements of RHS can be found in Peters et al. (2005).

Mostly RHS are measured using active LP-DOAS. Thus the obtained mixing ratios are an average along kilometerlong light paths and one has to keep in mind that a possibly inhomogeneous distribution of the trace gases can not be resolved. Burkholder et al. (2004) state that the mixing ratios derived from long path absorption measurements are too low to account for the large aerosol production observed. They suggest an inhomogeneous source distribution resulting in areas with much above average IO mixing ratios, socalled "hot-spots", to explain the significant particle formation. They conclude that their hypothesis has to be confirmed by further field studies.

In this study we present results from active LP-DOAS measurements of RIS on two almost parallel light paths of different lengths $(1034 \mathrm{~m}$ and $3946 \mathrm{~m})$, where the shorter light path was just crossing the intertidal area, in order to obtain information about the source distribution.

The first section addresses the instrument set-up and the measurement site, followed by a description of the DOAS analysis. In next sections results will be presented and discussed. We conclude with a summary and an outlook.

\section{Experimental}

\subsection{The active LP-DOAS system}

DOAS (Platt and Perner, 1983; Platt and Stutz, 2008) is a well established technique to identify and quantify trace gases by their narrow band absorption structures. In this study we used an active LP-DOAS instrument for the detection of the following RIS: IO, OIO and $\mathrm{I}_{2}$. The setup of the LP-DOAS system used was a further development of the coaxial mirror system introduced by Axelson et al. (1990). The light of a high pressure Xe-arc lamp of the type XBO500 (Osram) was collimated into six transmitting fibres of a Y- fibre bundle. The bundle at the telescope side consists of one receiving fibre surrounded by the six transmitting fibres. The transmitting fibres illuminate the mirror of the telescope yielding an almost parallel light beam, the receiving fibre is connected to the spectrometer. A detailed description of the Fibre LP-DOAS can be found in (Merten et al., 2009; Merten, 2008). The almost parallel light beam is then alternately sent on two different light paths through the open atmosphere to two arrays of quartz prism retro-reflectors (63 mm diameter each prism) located at distances of $1973 \mathrm{~m}$ and $517 \mathrm{~m}$. The number of quartz prisms in the arrays was 39 and 13, respectively. The reflected light was transmitted to an Acton 500 pro spectrometer (f-number $=6.9,600 \mathrm{gr} / \mathrm{mm}$ grating, focal length $=500 \mathrm{~mm}$, thermostated to $25^{\circ} \mathrm{C}$ ) via the receiving fibre of the fibre bundle, where it was analyzed. Spectroscopy requires a homogeneous illumination of the spectrometer grating. To obtain this, quartz glass fibres are used in order to "mix" the light and thus obtain a homogeneous illumination of the spectrometer. Different fibres can exhibit different mixing properties. The mixing can be improved by exerting mechanical stress on the fibres applying a mode mixer (Stutz and Platt, 1997), but mixing is often limited depending on the fibre characteristics. A good mixing of the light is especially important for very short light paths, as then the image of the retro reflectors is sharper, or if the applied light source features strong spectral structures in the respective wavelength range (which is the case in the evaluation wavelength range of IO). If the mixing is not perfect, small spectral structures may arise, which can correlate/anticorrelate with absorption structures. This is probably the reason for the bias we see in the IO data (see Sect. 4.3).

A reference spectrum was taken before and after each measurement spectrum using a shortcut system consisting of an aluminium diffuser plate that was placed several $\mathrm{mm}$ in front of the fibre bundle thus recording a lamp spectrum without passage through the atmosphere. The detector was a 1024 pixel photodiode array detector (type Hamamatsu S3904-1024). The resulting spectral resolution was about $0.5 \mathrm{~nm}$ FWHM. Four different wavelength ranges were successively covered to measure the trace gases of interest: $\mathrm{BrO}$ in $320 \pm 40 \mathrm{~nm}, \mathrm{IO}$ in $430 \pm 40 \mathrm{~nm}, \mathrm{OIO}$ and $\mathrm{I}_{2}$ in $550 \pm 40 \mathrm{~nm}$ and $\mathrm{NO}_{3}$ in $640 \pm 40 \mathrm{~nm}$. The latter measurements were only performed at solar zenith angles $>85^{\circ}$. These wavelength ranges also cover other species, such as $\mathrm{O}_{3}, \mathrm{NO}_{2}, \mathrm{H}_{2} \mathrm{O}, \mathrm{O}_{4}$, $\mathrm{SO}_{2}, \mathrm{HONO}$ and $\mathrm{HCHO}$, which were taken into account for the analysis. A full LP-DOAS measurement sequence took about 12 min for good visibility conditions and three wavelength ranges. A measurement sequence started with a lamp reference spectrum with 15 scans, followed by the measurement of the atmospheric spectrum with maximum 30 scans within $30 \mathrm{~s}$ and a second lamp reference spectrum of 15 scans. Afterwards background spectra were taken with a fixed integration time of 10 seconds. In the process of the analysis, the two lamp reference spectra were added to one shortcut spectrum for each atmospheric spectrum, in order to 
provide the ideal sensitivity. Since the detection limit of the longer light path was expected to be lower for homogeneous distributed trace gases, we performed measurements on the short light path during every fourth measurement cycle. The analysis procedure itself will be described in Sect. 3 .

\subsection{The passive MAX-DOAS systems}

In addition to the active instrument, two passive MAXDOAS instruments were applied to detect RIS. The MAXDOAS technique was already described in detail (e.g., Hönninger and Platt, 2002; Hönninger et al., 2004). The instruments used, were "Mini-MAX-DOAS-devices" (Bobrowski et al., 2003). Scattered sunlight is focussed by a quartz lens (focal length $=40 \mathrm{~mm}, \mathrm{~d}=20 \mathrm{~mm}$, aperture angle $<0.6^{\circ}$ ) and transmitted to a miniature crossed Czerny-Turner spectrometer/detector unit ("USB2000", Ocean Optics, Inc.) via a fibre bundle. The whole set up is placed in a sealed, weatherproof aluminium box which also contains the peltier cooler to stabilize the spectrometer to $0^{\circ} \mathrm{C}$. An attached stepper motor allows the instrument to observe scattered sunlight at a series of different elevation angles. The whole instrument was controlled by PC via USB connection. The two instruments covered the fixed wavelength ranges $325-461 \mathrm{~nm}$ for the detection of $\mathrm{BrO}$ and $\mathrm{IO}$ and $538-635 \mathrm{~nm}$ for OIO and $\mathrm{I}_{2}$, respectively. Their viewing azimuth was set up almost parallel to the light paths of the active instrument. Spectra were taken under $2^{\circ}, 4^{\circ}, 6^{\circ}, 10^{\circ}, 20^{\circ}$ and $90^{\circ}$ elevation angle for a fixed integration time of $300 \mathrm{~s}$ for each angle. Thus a full sequence took $30 \mathrm{~min}$.

\subsection{Particle measurements}

Particle measurements were carried out by a nano scanning mobility particle sizer (nano-SMPS), covering the size range from $3 \mathrm{~nm}$ to $20 \mathrm{~nm}$, and a standard SMPS, covering the $10 \mathrm{~nm}$ to $100 \mathrm{~nm}$ range. Both, the nano-SMPS and SMPS were standard Thermo Systems Inc. (TSI) systems (Wang and Flagan, 1990), with the nano-SMPS using the TSI 3025a condensation particle counter (CPC) as a detector and the SMPS using a TSI 3010 CPC as a detector. The instruments were located about $150 \mathrm{~m}$ away from the low tide region and sampling was conducted through a $3 \mathrm{~m}$ long, ${ }_{4}^{1}$ " stainless steel inlet. Size resolved concentrations were corrected for diffusional losses, which were calculated on the basis of tube diameter and residence time in the sample tube using the equations given by Seinfeld and Pandis (1998).

\subsection{Site description}

Between 3 August and 9 September 2007, an intensive field campaign was conducted at the Martin Ryan Institute (MRI) in Carna $\left(53.31^{\circ} \mathrm{N}, 9.83^{\circ} \mathrm{W}\right)$ at the Irish West Coast, about $6 \mathrm{~km}$ south-east from Mace Head. A description of the area around Carna can be found in e.g. Hebestreit (2001). The

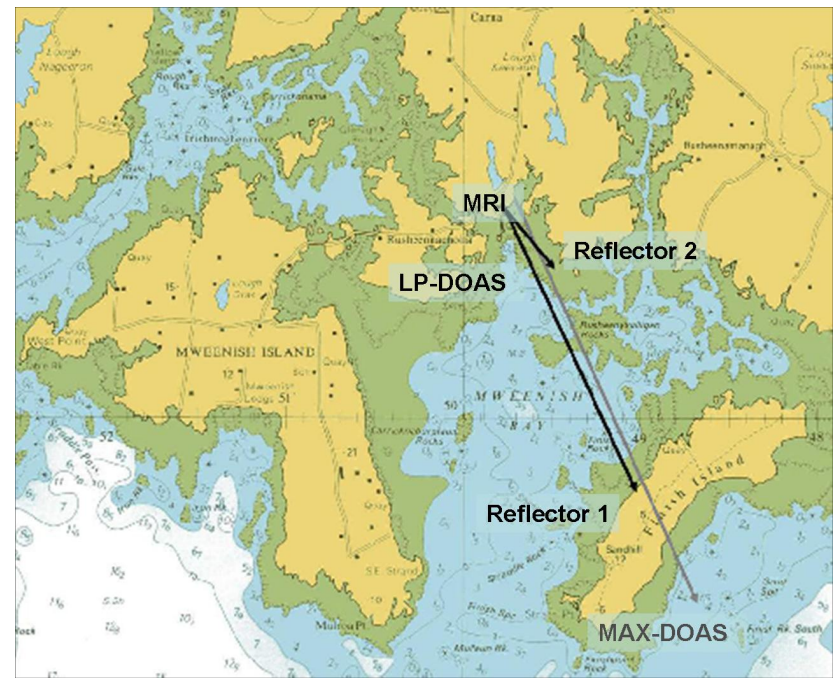

Fig. 1. Measurement site, the light paths of the active LP-DOAS are indicated in black arrows, the grey arrow indicates the viewing direction of the MAX-DOAS instruments. The green area marks the intertidal zone.

${ }^{\circledR}$ Crown Copyright and/or database rights. Reproduced by permission of the Controller of Her Majestys Stationery Office and the UK Hydrographic Office (www.ukho.gov.uk).

MRI is located in front of Mweenish Island (see Fig. 1), an island with a very high seaweed density. Due to its high seaweed density in all wind directions, the area has already been the object of earlier field measurements (e.g., Sellegri et al., 2005).

During the campaign the wind direction was almost all the time North/North-West. The weather was sunny during most of the days, with just few rainy days. Due to the sunny weather and the vast seaweed abundance, particle bursts were observed almost each day. An example for such a particle burst observed at 30 August can be found in Fig. 2. We concentrate on a core period of five days of measurements between 30 August and 4 September, since only during those five days we were able to detect IO on both LPDOAS light paths. Of the five days of observation, 31 August and 2 September were rainy, whereas the other three days were sunny and partly cloudy but with no rain and good visibility. During the five days a maximal tidal range of $4.4 \mathrm{~m}$ was observed.

The instruments were positioned at few meters distance from the waterfront during high tide. The light beam of the active LP-DOAS instrument was crossing the water at an altitude of about $5 \mathrm{~m}$ above sea level at high tide. During low tide the water below the short absorption path was completely removed, whereas the long light path crossed the same intertidal area first, then the sea and again an intertidal area in front of Finish Island, where the second retro-reflector was placed. Figure 1 shows the area of the MRI and the 

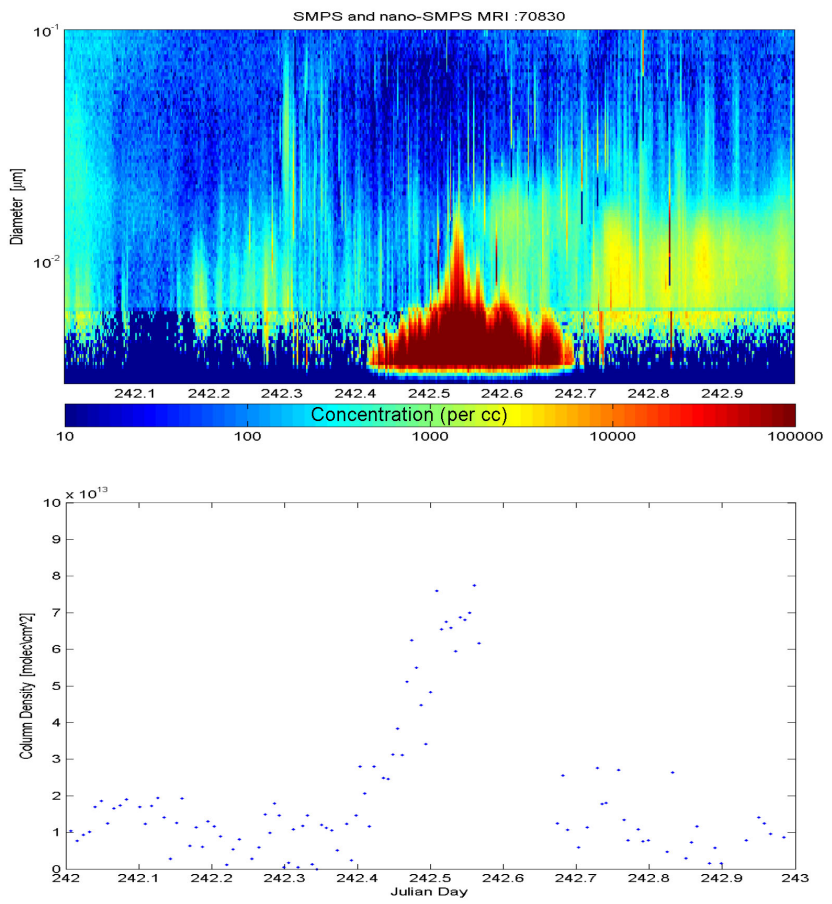

Fig. 2. Particle burst event measured 30 August (Julian date and time) with a nano-SMPS instrument (upper panel). After noon particle concentrations up to $10^{6} \mathrm{~cm}^{-3}$ particles were observed. The time of the event correlates well with low tide and high IO column densities measured along the long light path (lower panel).

absorption paths. It can be seen, that due to the slight angle between the two light paths, the long light path crosses less intertidal area in front of the instrument. Figure 3 demonstrates that the seaweed of the area is mainly dominated by the type Laminaria, which are known to be strong emitters of $\mathrm{I}_{2}$ as well as halocarbons (e.g., McFiggans et al., 2004; Carpenter et al., 2001; Ball et al., 2009).

\section{DOAS data analysis}

\subsection{Active LP-DOAS}

For the analysis of the LP-DOAS spectra the software DOASIS (Kraus, 2005) was used to simultaneously fit the different references to the atmospheric spectrum using a non-linear least-squares method (e.g., Stutz and Platt, 1996). Laboratory studies previous to the campaign showed that the detection limit of the instrument could be improved by taking reference spectra of the light source as close in time to the measurement spectrum as possible. Therefore two lamp reference spectra (shortcut spectra), one directly before and one directly after the measurement spectrum, were recorded, added and included in the fit. In addition a polynomial was included to account for broad band absorption structures,
Table 1. Differential absorption cross sections used for the analysis of the spectra.

\begin{tabular}{ll}
\hline Species & Reference \\
\hline $\mathrm{BrO}$ & Wilmouth et al. (1999) \\
$\mathrm{O}_{4}$ & Greenblatt et al. (1990) \\
$\mathrm{NO}_{2}$ & Voigt et al. (2002) \\
$\mathrm{I}_{2}$ & Saiz-Lopez et al. (2004b) \\
$\mathrm{OIO}$ & Bloss et al. (2001) \\
$\mathrm{IO}$ & Spietz et al. (2005) \\
$\mathrm{H}_{2} \mathrm{O}$ & Rothman et al. (2005) \\
$\mathrm{NO}_{2}($ MAX-DOAS) & Vandaele et al. (1998) \\
$\mathrm{O}_{3}(243 \mathrm{~K}$, MAX-DOAS) & Bogumil et al. (2003) \\
$\mathrm{O}_{3}(223 \mathrm{~K}$, MAX-DOAS) & Voigt et al. (2001) \\
\hline
\end{tabular}

broad band structures due to scattering in the atmosphere and broad band instrument features. On the basis of Stutz and Platt (1996) the statistical error of our analysis was multiplied by a factor 2 , to obtain the real measurement error. The detection limit is estimated by multiplying a factor 2 to the $1 \sigma$ statistical error.

IO was analyzed in the wavelength range between 416 and $448.5 \mathrm{~nm}$ where four of the strongest vibrational bands of the electronic transition $A^{2} \Pi_{3 / 2} \leftarrow X^{2} \Pi_{3 / 2}$ are. Due to large structures in the residual arising from the Xe-lamp, the wavelength range between $442 \mathrm{~nm}$ and $444 \mathrm{~nm}$ was excluded from the fit. In addition to the IO cross section references of $\mathrm{NO}_{2}, \mathrm{O}_{4}$ and $\mathrm{H}_{2} \mathrm{O}$ were included in the fit procedure. Table 1 summarizes the absorption cross sections used in this work. The polynomial included was of 5 th order. Figure 4 shows a sample evaluation of 30 August 2007, 13:26 UTC, taken on the long light path. The spectrum corresponds to a column density of $(7.8 \pm 0.72) \times 10^{13} \mathrm{molec} / \mathrm{cm}^{2}$. Assuming homogenous mixing along the $3946 \mathrm{~m}$ light path, this would correspond to a mixing ratio of $(7.9 \pm 0.73) \mathrm{ppt}$.

The evaluation of OIO and $\mathrm{I}_{2}$ was performed in the wavelength range between 530 and $567 \mathrm{~nm}$. This covers 6 vibrational bands of $\mathrm{OIO}$ and 15 vibrational bands of the electronic transition $\mathrm{B}^{3} \Pi\left(0_{u}^{+}\right)-X^{1} \Sigma_{g}^{+}$of $\mathrm{I}_{2}$. Besides the cross sections of $\mathrm{OIO}$ and $\mathrm{I}_{2}$, references of $\mathrm{NO}_{2}, \mathrm{O}_{4}$ and $\mathrm{H}_{2} \mathrm{O}$ and a 4 th order polynomial were included in the fit.

\subsection{MAX-DOAS}

For the evaluation of the MAX-DOAS measurements the software WinDOAS (Fayt and van Rozendael, 2001) was used to perform a non-linear least-squares fit. A description of the evaluation procedure can be found in Hönninger and Platt (2002). To detect the absorbers of interest, a $90^{\circ}$ reference spectrum of the same sequence, a Ring spectrum, a polynomial to account for Rayleigh and Aerosol scattering, an intensity offset (polynomial of degree 2) to account for possible instrument stray light and cross sections of all other absorbers were fitted to the atmospheric spectrum. The 


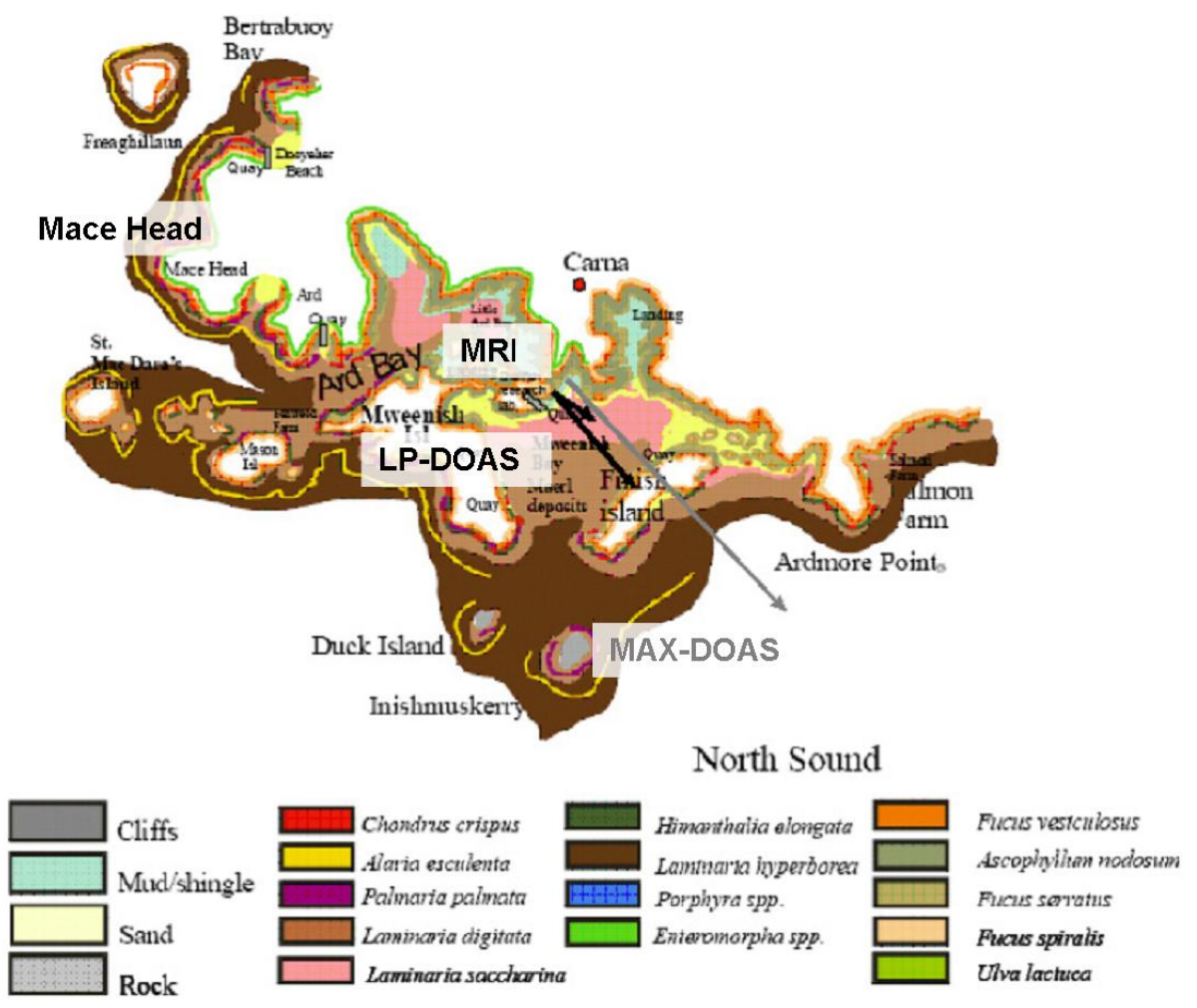

Fig. 3. Seaweed distribution in the vicinity of the MRI: Most of the seaweed is of the type Laminaria. The short light path crosses almost exclusively Laminaria Saccharina, whereas the long light path crosses first Laminaria Saccharina and then Laminaria Digitata. Adapted from [Connemara Seaweed Survey 2001. Irish Seaweed Centre, NUIG Internal report 72 pp.].

Table 2. Overview of the analysis settings

\begin{tabular}{llll}
\hline Species & Wavelength range $[\mathrm{nm}]$ & Polynomial [order] & Trace gas references applied \\
\hline IO & $416-448.5$ & 5 th & $\mathrm{NO}_{2}, \mathrm{H}_{2} \mathrm{O}, \mathrm{O}_{4}$ \\
I $/$ OIO & $530-567$ & 4 th & $\mathrm{NO}_{2}, \mathrm{H}_{2} \mathrm{O}, \mathrm{O}_{4}$ \\
IO (MAX-DOAS) & $414-438$ & $3 \mathrm{rd}$ & $\mathrm{O}_{4}, \mathrm{NO}_{2}$ \\
$\mathrm{O}_{4}$ (MAX-DOAS) & $338.5-367$ & $3 \mathrm{rd}$ & $\mathrm{O}_{3}, \mathrm{NO}_{2}, \mathrm{BrO}$ \\
$\mathrm{I}_{2} /$ OIO (MAX-DOAS) & $553-567$ & $3 \mathrm{rd}$ & $\mathrm{O}_{3}, \mathrm{H}_{2} \mathrm{O}, \mathrm{O}_{4}, \mathrm{NO}_{2}$ \\
\hline
\end{tabular}

results of the evaluation are therefore "differential slant column densities" (dSCDs), i.e. $\mathrm{S}_{\mathrm{dSCD}}=\mathrm{S}(\alpha)-\mathrm{S}\left(90^{\circ}\right)$, where $\mathrm{S}$ denotes the signal of the respective absorber $\left[\mathrm{molec} / \mathrm{cm}^{2}\right]$ and $\alpha$ the elevation angle. An overview of the MAX-DOAS analysis setting applied is given in Table 2. A MAX-DOAS sample evaluation of 30 August 2007, 14:04 UTC is shown in Fig. 5. The spectrum corresponds to a column density of $(5.5 \pm 0.4) \times 10^{13} \mathrm{molec} / \mathrm{cm}^{2}$.

\section{Results and discussion}

\subsection{MAX-DOAS measurements}

During the five days of observation OIO and $\mathrm{I}_{2}$ could not be detected with the MAX-DOAS instruments. While the analysis yielded periods where the differential slant column densities (dSCDs) exceeded the detection limit, which was for the $2^{\circ}$ angle on average $1.4 \times 10^{14} \mathrm{molec} / \mathrm{cm}^{2}$ for OIO and $5.6 \times 10^{14} \mathrm{molec} / \mathrm{cm}^{2}$ for $\mathrm{I}_{2}$, the results did not withstand different sensitivity studies: A change of the analysis wavelength range to $547-567 \mathrm{~nm}$ changed the results as significantly as changing the order of the polynomial to 2 or changing the intensity offset to first order. 

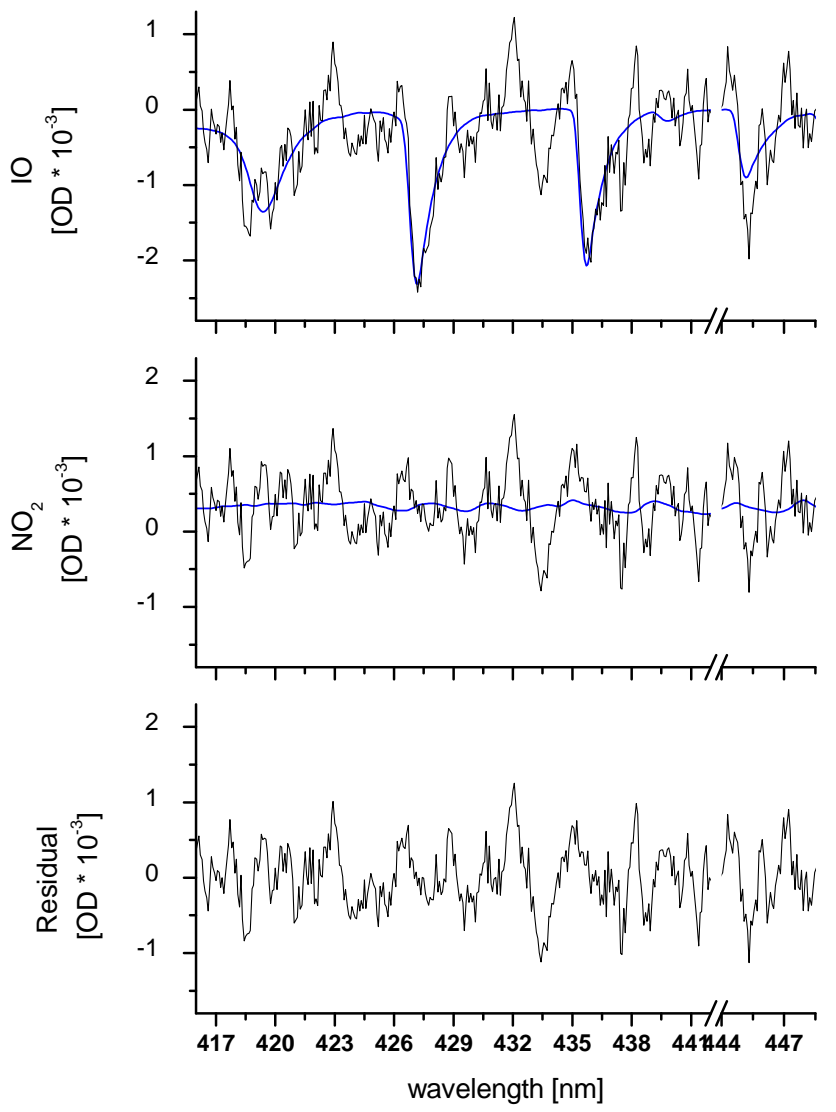

Fig. 4. Example for the spectral identification of IO on the long light path using the active LP-DOAS instrument. The spectrum was recorded 30 August 2007, 13:26 GMT. The corresponding mixing ratio of IO is $(7.9 \pm 0.73) \mathrm{ppt}$.

On all five days IO exceeded the average detection limit of $2.8 \times 10^{13} \mathrm{molec} / \mathrm{cm}^{2}$, also sensitivity studies indicated the results to be robust. The maximum dSCD observed was $1.0 \times 10^{14} \mathrm{molec} / \mathrm{cm}^{2}$ (Fig. 6). While under an elevation angle of $2^{\circ}$ the dSCDs are very high, especially around low tide, the dSCDs decrease rapidly for higher elevation angles. The decrease of dSCDs for higher elevation angles is generally expected for tropospheric absorbers, because the light path through the trace gas layer is longer for lower elevation angles. However, the separation of the different elevation angles can also be caused by a vertical gradient of the trace gas itself. Since the source of IO is located on the ground, one would expect a vertical gradient of the IO concentration. To distinguish between the two effects radiative transport modelling would be necessary. The quite heterogenous distribution of IO and rather high noise would make the radiative transfer modelling and its interpretation a quite difficult task that is beyond the scope of this work. However, we used an approximation via $\mathrm{O}_{4}$ to obtain information about the vertical distribution of IO: the profile of $\mathrm{O}_{4}$ is essentially invariable (except for small changes due to changing air density) and therefore changes in the dSCDs of $\mathrm{O}_{4}$ are caused by changes of the light path due to scattering in the atmosphere. For a constant profile of IO in the lowest few hundred meters, one would expect the $\mathrm{IO} / \mathrm{O}_{4}$ ratio to be rather constant for different elevation angles, whereas for a vertical gradient with higher IO concentrations close to the ground, the ratio should be higher for lower elevation angles. Figure 10 shows the $\mathrm{IO} / \mathrm{O}_{4}$ ratio for the five days of measurement. For $2^{\circ}$ elevation angles, the ratio is significantly higher, indicating a strong vertical gradient.

\subsection{LP-DOAS measurements}

OIO could not be identified unambiguously during the 5 days. Even though the column densities exceed the statistical $2 \sigma$ detection limit $\left(1.2 \times 10^{14} \mathrm{molec} / \mathrm{cm}^{2}\right.$ or $\approx 12 \mathrm{ppt}$ on the long and $1.8 \times 10^{14} \mathrm{molec} / \mathrm{cm}^{2}$ or $\approx 70 \mathrm{ppt}$ on the short light path) several times by up to a factor of 2 , the fact that the analysis shows strong scattering and yields negative column densities of the same order of magnitude as the positive values (up to about $-4 \times 10^{14} \mathrm{molec} / \mathrm{cm}^{2}$ on the short, and $-5 \times 10^{14} \mathrm{molec} / \mathrm{cm}^{2}$ on the long light path) makes the interpretation difficult. Although the analysis was stable using different fit parameters, no further conclusions about the horizontal distributions can be drawn at this time.

OIO measurements are reported from various sites: At Mace Head up to 6.7 ppt were reported (Hebestreit, 2001; Saiz-Lopez and Plane, 2004b), Allan et al. (2001) report up to $3.0 \mathrm{ppt}$ from Cape Grim, Tasmania, Stutz et al. (2007) saw up to 30 ppt in the Gulf of Maine and Mahajan et al. (2009) saw a maximum of $8.7 \mathrm{ppt}$ in Roscoff, France. For our measurements, the OIO mixing ratios are below the detection limit of our instrument when measuring along the long light path. Therefore our results are not in contradiction to earlier studies. However, since Mweenish Bay is an area of high seaweed density, one could speculate that the OIO mixing ratios at Mweenish Bay could be higher than those reported from, e.g. Mace Head.

Since $I_{2}$ is evaluated in the same spectral wavelength range as OIO, its evaluation shows the same problems. Again, the column densities exceed the statistically derived detection limit several times by about a factor of 2 , but due to the short light path, the results show a strong scattering also towards negative column densities. Similar to OIO the analysis proved to be stable, but anyway no conclusions about the horizontal distribution can be derived. The average detection limit was $4.9 \times 10^{14} \mathrm{molec} / \mathrm{cm}^{2}$ or $\approx 50 \mathrm{ppt}$ on the long light path and $7.3 \times 10^{14} \mathrm{molec} / \mathrm{cm}^{2}$ or $\approx 282 \mathrm{ppt}$ on the short light path. The maximum in negative column densities obtained from the evaluation was about $-5.5 \times 10^{14} \mathrm{molec} / \mathrm{cm}^{2}$ and $-8.9 \times 10^{14} \mathrm{molec} / \mathrm{cm}^{2}$, respectively.

$\mathrm{I}_{2}$ has so far been observed at Mace Head (Saiz-Lopez and Plane, 2004b; Bitter et al., 2005; Peters et al., 2005; Huang et al., 2010), at Roscoff, France (Mahajan et al., 2009) and 

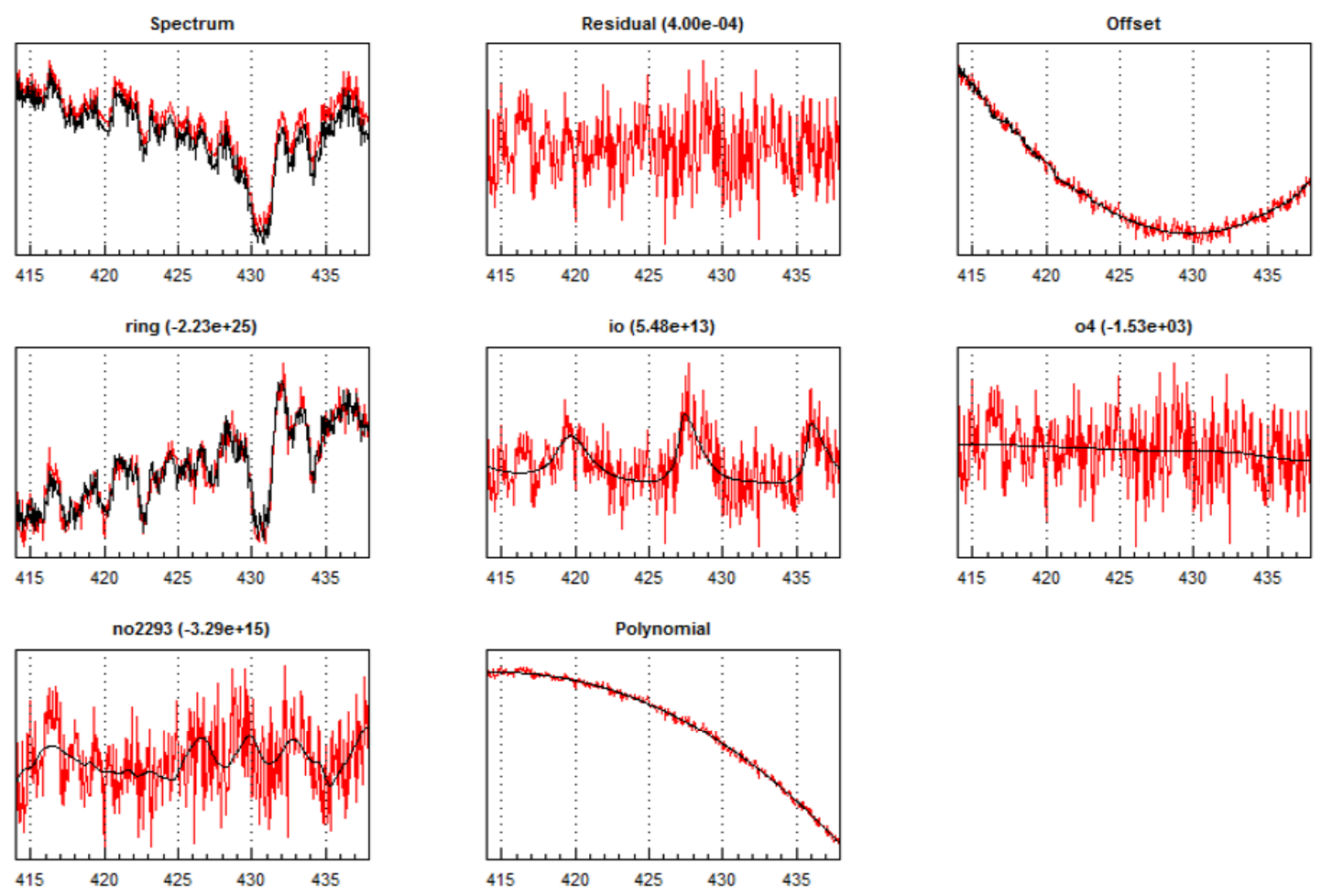

Fig. 5. Example for the spectral identification of IO using the passive MAX-DOAS instrument. The spectrum was recorded 30 August 2007 , 14:05 GMT under $4^{\circ}$ elevation angle. The corresponding differential slant column density of IO is $(5.5 \pm 0.4) \times 10^{13} \mathrm{molec} / \mathrm{cm}^{2}$.

at Mweenish Bay (Saiz-Lopez et al., 2006b; Huang et al., 2010) where maximum mixing ratios of $140.7 \mathrm{ppt}, 52.3 \mathrm{ppt}$ and $193.3 \mathrm{ppt}$ are reported, respectively. Of special interest for our measurements are the results of Huang et al. (2010), who measured up to $193.3 \mathrm{ppt}$ of $\mathrm{I}_{2}$ at the MRI when also LP-DOAS measurements were performed. However, Huang et al. (2010) used an in-situ technique and were measuring very close to the ground in the intertidal area. Although the detection limit of the long light path is considerably lower than the reported concentrations, $50 \mathrm{ppt}$ along the entire light path and at about $5 \mathrm{~m}$ height would be required. So the fact, that we were not able to detect $I_{2}$, is probably an indication that it is not homogenously distributed.

IO was detected on both light paths on each day. The average detection limit was $2.2 \times 10^{13} \mathrm{molec} / \mathrm{cm}^{2}$ or $\approx 2.2 \mathrm{ppt}$ on the long light path and $3.6 \times 10^{13} \mathrm{molec} / \mathrm{cm}^{2}$ or $\approx 14$ ppt on the short light path. The maximum observed column densities were $8.0 \times 10^{13} \mathrm{molec} / \mathrm{cm}^{2}$ and $7.4 \times 10^{13} \mathrm{molec} / \mathrm{cm}^{2}$, respectively.

\subsection{Discussion and comparison}

Figure 7 shows the time series of IO column densities on both light paths (black stars: long light path, blue triangles: short light path). The blue line indicates tidal height and the grey shaded areas mark the periods of darkness. The peaks

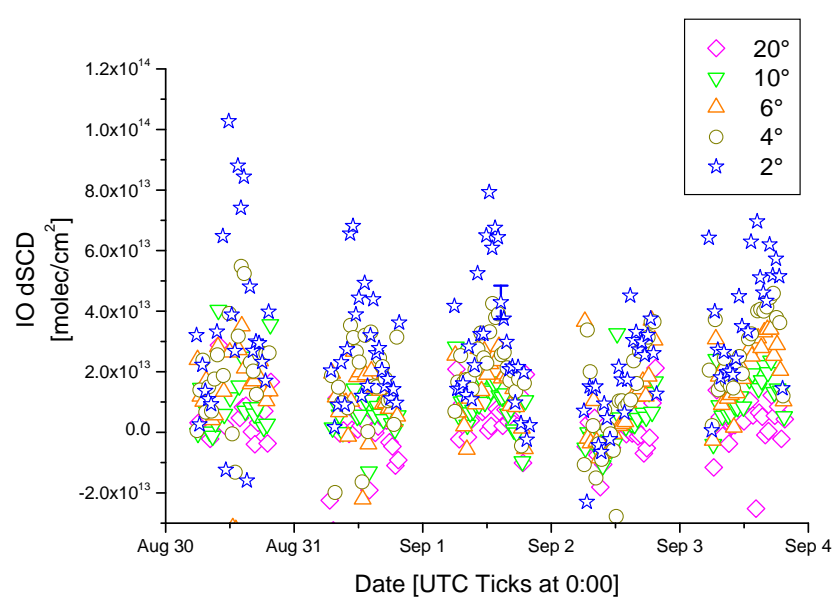

Fig. 6. IO dSCDs, different colors/symbols represent different elevation angles. A clear separation between different elevation angles can be seen with higher signals for lower angels, indicating a strong vertical gradient. For 1 September a typical error bar is given.

in IO are correlated to minima in tidal height and maxima in solar radiation. This was also observed during earlier campaigns at Mace Head (e.g., Alicke et al., 1999; Saiz-Lopez et al., 2006b), and also at the French Atlantic Coast (Peters 


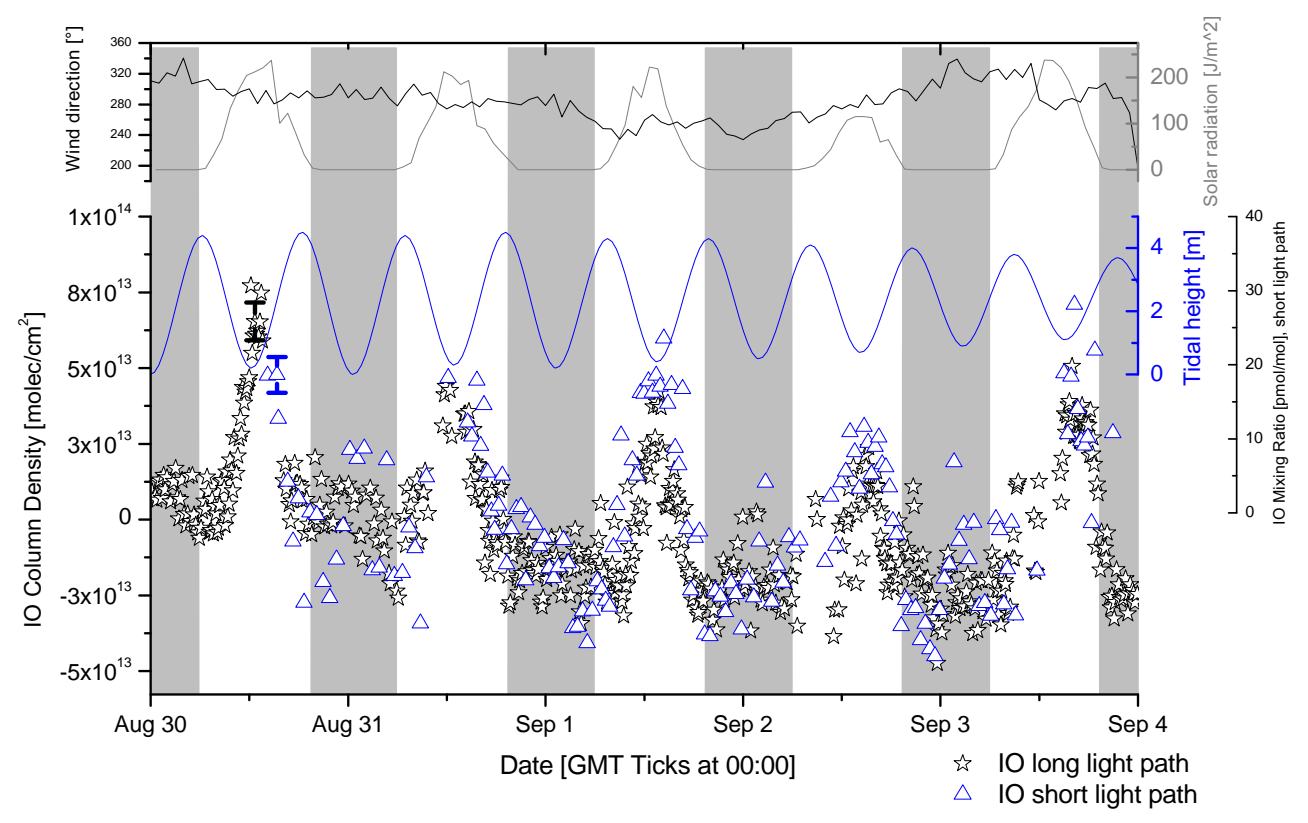

Fig. 7. Time series of IO on both active LP-DOAS light paths. The blue line indicates the tidal height and grey shaded areas mark periods of darkness. Blue triangles correspond to the IO column density seen over the short light path, black stars to the long light path. In the upper panels, solar radiation and wind direction are shown. The peaks in IO coincide with minima in tidal height and maxima in solar radiation. The column densities measured on both light paths are comparable indicating most of the IO signal originating in the intertidal area.

et al., 2005; Mahajan et al., 2009). Stutz et al. (2007) saw no dependence of the IO signal on tidal height, which is so far unexplained.

A striking feature is the observation that the column densities on the long light path are about the same as on the short although also some differences are found. This is a strong indication that the signal comes to a large fraction from the intertidal area. Converting the maximum IO column density $(7.4 \pm 2.3) \times 10^{13} \mathrm{molec} / \mathrm{cm}^{2}$ of the short light path into mixing ratios, assuming $1034 \mathrm{~m}$ path length and homogenous mixing, yields $(29 \pm 8.8)$ ppt. Assuming that IO is also inhomogenously distributed within the intertidal area, this is in good agreement with modelling studies of Burkholder et al. (2004), who state that 50 to $100 \mathrm{ppt}$ of IO are needed to explain nucleation events with particle concentration of $10^{6} \mathrm{~cm}^{-3}$ similar to those that were observed each of the 5 days. An example for the correlation between enhanced IO column densities measured along the long light path and particle formation is illustrated in Fig. 2. The particle burst (upper panel) at noon coincides with elevated IO column densities (lower panel). A plot with total particle concentration vs. IO column densities can be found in Huang et al. (2010). The reason that our IO signal is still below the necessary 50 $100 \mathrm{ppt}$, that are needed, might be the strong vertical gradient, we see in the MAX-DOAS data. As our light path crosses the seaweed at several meters height, the concentrations further down, are probably significantly higher.
We also feel that we can explain the slight differences in the column densities seen at the two light paths. On 30 August we started measurements on the short light path at 14:13 GMT. Until 2 September, the column densities are about the same as for the long light path. On 3 September the column density of the short light path exceeds the column density of the long light path by about $50 \%$. This is not due to a change in wind direction (same wind direction on $30 \mathrm{Au}-$ gust and 3 September), but because of the slightly different light paths and because of different sources. Figure 1 shows that the long light path crosses less intertidal area in front of the instrument due to a slight angle between the viewing directions. Figure 8 illustrates the LP-DOAS measurement set-up for different water levels. While the intertidal area below the short light path is exposed to ambient air during low tide for all days, due to the steep coast line, more intertidal area in front of Finish Island is exposed close to low spring tide (30 August). During spring tide the deep water seaweed Laminaria Digitata exposed in front of Finish Island probably makes up the difference in column densities due to the shorter fraction of intertidal area at the MRI for the long light path, whereas the following days its IO input decreases. Note that in the afternoon of 31 August, the fibre had to be exchanged. The fibre effects explained in Sect. 2.1 can cause a bias in the observed concentrations and therefore the column densities observed after 31 August, 14:00 might be underestimated. 


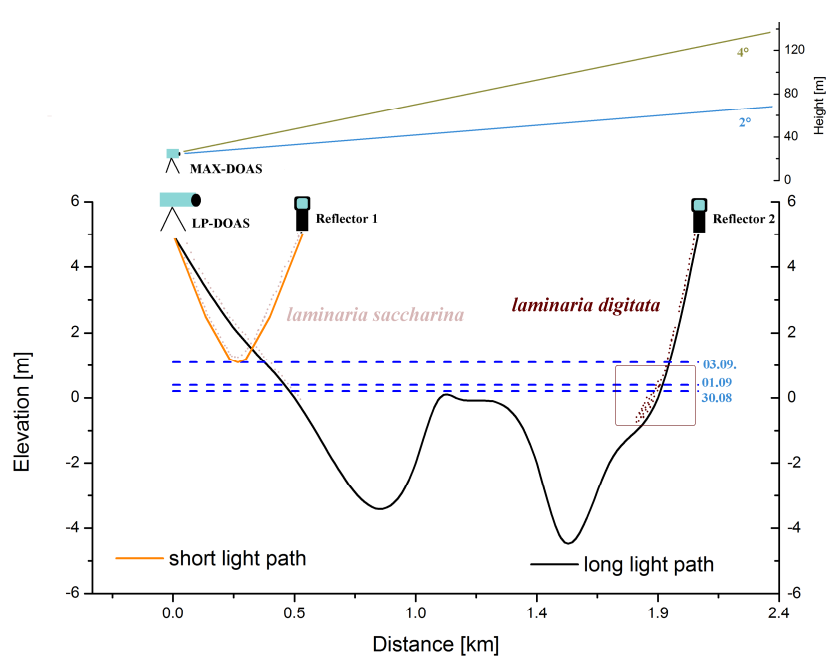

Fig. 8. Sketch of measurement set-up. Low tide water levels for 30 August, 1 and 3 September, 2007 are shown. The short light path crosses mainly Laminaria Saccharina, which are exposed during low tide for all days of measurement. The long light path crosses Laminaria Saccharina first and Laminaria Digitata on the other side of Mweenish Bay. Due to the steeper coast line on the other side of the bay, more seaweed is exposed along the long light path during periods of low spring tide (highlighted with box).

Figure 9 shows a comparison of the $2^{\circ}$ and $4^{\circ}$ MAXDOAS IO dSCDs (blue stars and black circs, respectively) with the column densities of the LP-DOAS instrument (long light path: black crosses, short light path: pink triangles). An absolute agreement between the active and the passive data is not expected, since the light paths are significantly different. However, the data correlate well and it can be seen that the $2^{\circ}$ MAX-DOAS dSCDs are largely higher than the LP-DOAS column densities, while the $4^{\circ}$ results are about the same magnitude or lower than the LP-DOAS results. A striking feature is that the $2^{\circ}$ MAX-DOAS results are often a factor of 2 higher than the $4^{\circ}$ results. This is not only because of a longer light path, but also due to a vertical gradient of IO (Fig. 10).

Figure 11 shows the correlation between the $2^{\circ} \mathrm{MAX}$ DOAS dSCDs and the LP-DOAS column density along the long light path. The data show strong scatter, but although the intertidal area in front of the instrument is crossed just once, the MAX-DOAS shows higher column densities most of the time. This occurs mainly during low tide (see Fig. 8). There are probably two sources, which explain the higher MAX-DOAS signal: First, the MAX-DOAS instrument probably also probes the intertidal area on the other side of Finish Island (Fig. 3 shows that in the deeper water behind Finish Island Laminaria Hyperborea is located, which is a very strong emitter of iodine precursors; Ball et al., 2009), and second, it is possible, that light reflected from the surface and therefore passing a layer with very high IO con-

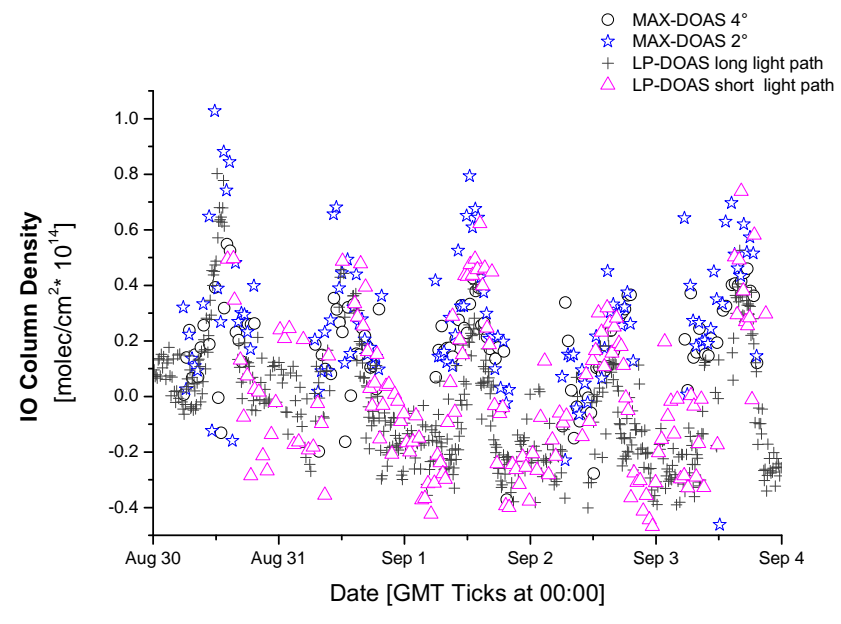

Fig. 9. Comparison of the column densities of the active LP-DOAS measurements with the differential slant column densities (dSCD) of the MAX-DOAS measurements at an elevation angle of $2^{\circ}$ and $4^{\circ}$. (LP-DOAS column densities, short light path: pink triangles, long light path: black crosses; MAX-DOAS dSCDs, $2^{\circ}$ : blue stars, $4^{\circ}$ : black circs).

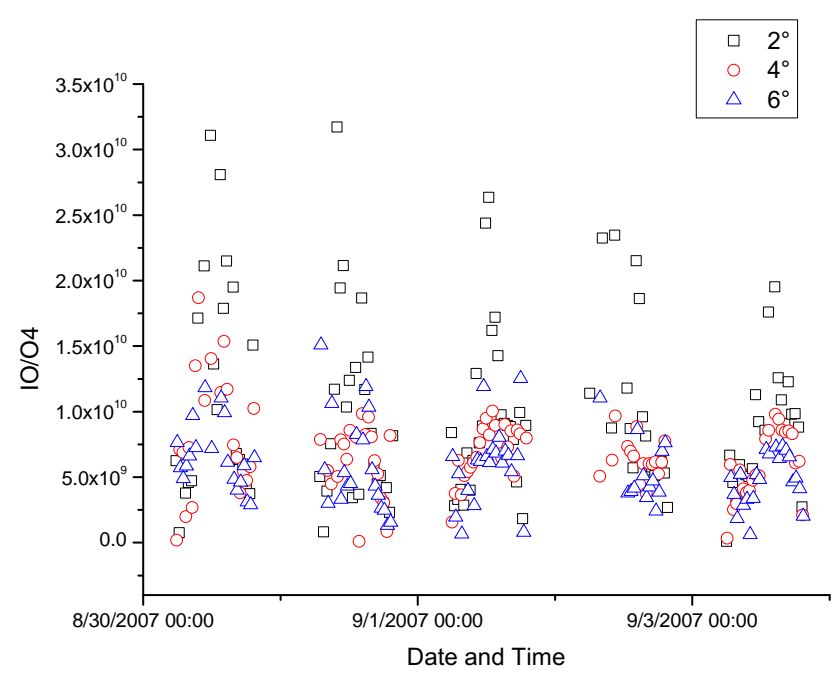

Fig. 10. Ratio of $\mathrm{IO}$ and $\mathrm{O}_{4}$ column densities. For $2^{\circ}$ elevation angle the ratio is significantly higher, indicating a strong vertical gradient of IO.

centrations, causes the higher signal. While water only has an albedo below $10 \%$, very high concentrations of IO close to the surface could have a significant impact on the results. Additionally light not reflected by the surface, but scattered by, e.g. aerosols close to the ground contributed to the measured IO signal.

As we know from the LP-DOAS results, the IO signal comes almost exclusively from the intertidal area, which means that the MAX-DOAS signal originates not only from 


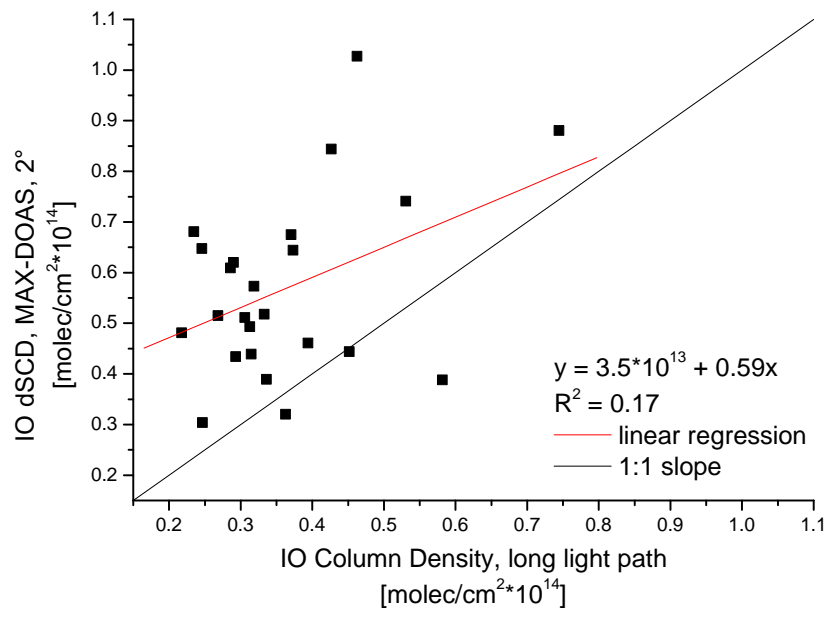

Fig. 11. Correlation between LP-DOAS (long light path) and $2^{\circ}$ MAX-DOAS IO column densities. Column densities of the long light path were interpolated to the time grid of the MAX-DOAS measurements. Only data above the detection limit are shown.

the intertidal zone in front of the MRI, but also from intertidal areas further away. If the IO was located only in the intertidal area, its lifetime must be very short. This also means that its concentration should decrease rapidly with height which is in good agreement with the strong decrease of the IO dSCDs towards higher elevation angles. But this also means that the additional signal, the MAX-DOAS detects (its light path only crosses the intertidal area in front of the MRI once) most likely does not come from too far away, as even for $2^{\circ}$ elevation after $2 \mathrm{~km}$, the instrument looks at a height of $70 \mathrm{~m}$ (see Fig. 8).

\section{Conclusions}

During this study OIO and $\mathrm{I}_{2}$ could not be observed above the detection limit for both light paths and both techniques. Therefore no information about their horizontal distribution could be obtained and more measurements with longer absorption paths and better detection limits just crossing intertidal area are needed.

IO could clearly be detected, with the observation angle dependence of the observed dSCDs indicating a vertical gradient in the IO concentration. Comparing the IO column densities of two different LP-DOAS light paths, where one light path was just crossing intertidal area, suggests that IO is almost exclusively located in this area. Assuming that its distribution in the intertidal area is also inhomogenous, we feel that we can confirm the so-called "hot-spot-theory" (e.g., Burkholder et al., 2004; Saiz-Lopez et al., 2006a), that was introduced to explain the formation of nucleation events as they have also been observed during this study.
Acknowledgements. This work was conducted under the MAP Project funded by the European Commission (under FP6 project number 018332). We thank the staff of MRI Carna, especially Richard Fitzgerald, for providing space and support during the campaign. We thank Roland von Glasow for helpful discussions. The efforts of Darius Ceburnis from NUIG are gratefully acknowledged. We also would like to thank Stefan Kraan from the Irish Seaweed Center for providing seaweed maps. The efforts of Darius Ceburnis from NUIG are gratefully acknowledged.

Edited by: R. Sander

\section{References}

Alicke, B., Hebestreit, K., Stutz, J., and Platt, U.: Iodine oxide in the marine boundary layer, Nature, 397, 572-573, 1999.

Allan, B. J., Plane, J. M. C., and McFiggans, G.: Observations of OIO in the remote marine boundary layer, Geophys. Res. Lett., 28, 1945-1948, 2001

Axelson, H., Galle, B., Gustavson, K., Ragnarsson, P., and Rudin, M.: A Transmitting / Receiving Telescope for DOASMeasurements using Retroreflektor Technique, Techn. Dig. Ser., 4, 641-644, 1990

Bale, C., Ingham, T., Commane, R., Heard, D., and Bloss, W.: Novel measurements of atmospheric iodine species by resonance fluorescence, J. Atmos. Chem., 60, 51-70, 2008.

Ball, S. M., Hollingsworth, A. M., Humbles, J., Leblanc, C., Potin, P., and McFiggans, G.: Spectroscopic studies of molecular iodine emitted into the gas phase by seaweed, Atmos. Chem. Phys. Discuss., 9, 26329-26376, 2009, http://www.atmos-chem-phys-discuss.net/9/26329/2009/.

Barrie, L., Bottenheim, J., Schnell, R., Crutzen, P., and Rasmussen, R.: Ozone destruction and photochemical reactions at polar sunrise in the lower Arctic atmosphere, Nature, 334, 138-141, 1988.

Bitter, M., Ball, S. M., Povey, I. M., and Jones, R. L.: A broadband cavity ringdown spectrometer for in-situ measurements of atmospheric trace gases, Atmos. Chem. Phys., 5, 2547-2560, 2005, http://www.atmos-chem-phys.net/5/2547/2005/.

Bloss, W. J., Rowley, D. M., Cox, R. A., and Jones, R. L.: Kinetics and Products of the IO Self-Reaction, J. Phys. Chem. A, 105, 7840-7854, 2001

Bobrowski, N., Hönninger, G., Galle, B., and Platt, U.: Detection of bromine monoxide in a volcanic plume, Nature, 423, 273-276, 2003.

Bogumil, K., Orphal, J., Homann, T., Voigt, S., Spietz, P., Fleischmann, O., Vogel, A., Hartmann, M., Bovensmann, H., Frerick, J., and Burrows, J.: Measurements of molecular absorption spectra with the SCIAMACHY pre- flight model: Instrument characterization and reference data for atmospheric remote sensing in the $230-2380 \mathrm{~nm}$ region., J. Photochemistry and Photobiology A, 157, 167-184, 2003

Burkholder, J. B., Curtius, J., Ravishankara, A. R., and Lovejoy, E. R.: Laboratory studies of the homogeneous nucleation of iodine oxides, Atmos. Chem. Phys., 4, 19-34, 2004, http://www.atmos-chem-phys.net/4/19/2004/

Carpenter, L. J., Hebestreit, K., Platt, U., and Liss, P. S.: Coasta zone production of IO precursors: a 2-dimensional study, Atmos. Chem. Phys., 1, 9-18, 2001, http://www.atmos-chem-phys.net/1/9/2001/. 
Carpenter, L. J.: Iodine in the marine boundary layer, Chem. Rev., 103, 4953-4962, 2003.

Dixneuf, S., Ruth, A. A., Vaughan, S., Varma, R. M., and Orphal, J.: The time dependence of molecular iodine emission from Laminaria digitata, Atmos. Chem. Phys., 9, 823-829, 2009, http://www.atmos-chem-phys.net/9/823/2009/.

Fayt, C. and van Rozendael, M.: WinDOAS, iSAB/BIRA Belgium, http://www.oma.be/BIRA-IASB, 2001.

Frieß, U., Wagner, T., Pundt, I., Pfeilsticker, K., and Platt, U.: Spectroscopic Measurements of Tropospheric Iodine Oxide at Neumeyer Station, Antarctica, Geophys. Res. Lett., 28, 19411944, 2001.

Furneaux, K. L., Whalley, L. K., Heard, D. E., Atkinson, H. M., Bloss, W. J., Flynn, M. J., Gallagher, M. W., Ingham, T., Kramer, L., Lee, J. D., Leigh, R., McFiggans, G. B., Mahajan, A. S., Monks, P. S., Oetjen, H., Plane, J. M. C., and Whitehead, J. D.: Measurements of iodine monoxide at a semi polluted coastal location, Atmos. Chem. Phys. Discuss., 9, 25737-25797, 2009, http://www.atmos-chem-phys-discuss.net/9/25737/2009/.

Greenblatt, G. D., Orlando, J. J., Burkholder, J. B., and Ravishankara, A. R.: Absorption Measurements of Oxygen between 330 and 1140 nm, J. Geophys. Res., 95, 18577-18582, 1990.

Hebestreit, K.: Halogen Oxides in the Mid-Latitudinal Planetary Boundary Layer, Doctoral thesis, Institut für Umweltphysik, Universität Heidelberg, http://www.ub.uni-heidelberg.de/archiv/ 1619, 2001.

Hoffmann, T., O’Dowd, C. D., and Seinfeld, J. H.: IO homogeneous nucleation: An explanation for coastal new particle formation, Geophys. Res. Lett., 28, 1949-1952, 2001.

Hönninger, G. and Platt, U.: Observations of $\mathrm{BrO}$ and its vertical distribution during surface ozone depletion at Alert, Atm. Env., 36, 2481-2489, 2002.

Hönninger, G., von Friedeburg, C., and Platt, U.: Multi axis differential optical absorption spectroscopy (MAX-DOAS), Atmos. Chem. Phys., 4, 231-254, 2004,

http://www.atmos-chem-phys.net/4/231/2004/.

Huang, R.-J., Seitz, K., O'Dowd, C., Platt, U., and Hoffmann, T.: Observations of high concentrations of I 2 and IO in coastal air supporting iodine-oxide driven coastal new particle formation, Geophys. Res. Lett., 37, 3, doi:10.1029/2009GL041467, 2010.

Jimenez, J. L., Bahreini, R., Cocker, D. R., Zhuang, H., Varutbangkul, V., Flagan, R. C., Seinfeld, J. H., O'Dowd, C. D., and Hoffmann, T.: New particle formation from photooxidation of diiodomethane $\mathrm{CH}_{2} \mathrm{I}_{2}$, J. Geophys. Res., 108(D10), 4318, doi:10.1029/2002JD002452, 2003.

Kraus, S.: DOASIS A Framework Design for DOAS, Doctoral thesis, Combined Faculties for Mathematics and for Computer Science, University of Mannheim, 2005.

Lee, J. D., McFiggans, G., Allan, J. D., Baker, A. R., Ball, S. M., Benton, A. K., Carpenter, L. J., Commane, R., Finley, B. D., Evans, M., Fuentes, E., Furneaux, K., Goddard, A., Good, N., Hamilton, J. F., Heard, D. E., Herrmann, H., Hollingsworth, A., Hopkins, J. R., Ingham, T., Irwin, M., Jones, C. E., Jones, R. L., Keene, W. C., Lawler, M. J., Lehmann, S., Lewis, A. C., Long, M. S., Mahajan, A., Methven, J., Moller, S. J., Mller, K., Müller, T., Niedermeier, N., O'Doherty, S., Oetjen, H., Plane, J. M. C., Pszenny, A. A. P., Read, K. A., Saiz-Lopez, A., Saltzman, E. S., Sander, R., von Glasow, R., Whalley, L., Wiedensohler, A., and Young, D.: Reactive Halogens in the Marine Boundary Layer
(RHaMBLe): the tropical North Atlantic experiments, Atmos. Chem. Phys., 10, 1031-1055, 2010,

http://www.atmos-chem-phys.net/10/1031/2010/.

Mahajan, A., Oetjen, H., Saiz-Lopez, A., Lee, J., McFiggans, G., and Plane, J.: Reactive iodine species in a semi-polluted environment, Geophysical Research Letters, 36, L16803, doi:10.1029/2009GL038018, 2009.

Mäkelä, J. M., Hoffmann, T., Holzke, C., Väkevä, M., Suni, T., Mattila, T., Aalto, P. P., Tapper, U., Kauppinen, E. I., and O’Dowd, C. D.: Biogenic iodine emissions and identification of endproducts in coastal ultrafine particles during nucleation bursts, J. Geophys. Res., 107(D19), 8110, doi:10.1029/2001JD000580, 2002.

McFiggans, G., Coe, H., Burgess, R., Allan, J., Cubison, M., Alfarra, M. R., Saunders, R., Saiz-Lopez, A., Plane, J. M. C., Wevill, D., Carpenter, L., Rickard, A. R., and Monks, P. S.: Direct evidence for coastal iodine particles from Laminaria macroalgae - linkage to emissions of molecular iodine, Atmos. Chem. Phys., 4, 701-713, 2004,

http://www.atmos-chem-phys.net/4/701/2004/.

Merten, A.: Neues Design von Langpfad-DOAS-Instrumenten basierend auf Faseroptiken und Anwendungen der Untersuchung der urbanen Atmosphäre, Doctoral thesis, University of Heidelberg, http://www.ub.uni-heidelberg.de/archiv/8499, 2008.

Merten, A., Tschritter, J., and Platt, U.: Novel design of DOASlong-path telescopes based on fiber optics, Appl. Optics, submitted, 2009.

O'Dowd, C. and de Leeuw, G.: Marine aerosol production: a review of the current knowledge, Phil. Trans. R. Soc. A, 365, 17531774, doi:10.1098/rsta2007.2043, 2007.

O’Dowd, C. D., Hämeri, K., Mäkelä, J., Pirjola, L., Kulmala, M., Jennings, S., Berresheim, H., Hansson, H.-C., de Leeuw, G., Kunz, G., Allen, A., Hewitt, C., Jackson, A., Viisanen, Y., and Hoffmann, T.: A dedicated study of New Particle Formation and Fate in the Coastal Environmnet (PARFORCE): Overview of objectives and achievements, J. Geophys. Res., 107, D19, 8108, doi:10.1029/2001JD000555, 2002.

Palmer, C., Anders, T., Carpenter, L., Kupper, F., and McFiggans, G.: Iodine and Halocarbon Response of Laminaria digitata to Oxidative Stress and Links to Atmospheric New Particle Production, Environ. Chem., 2, 282-290, doi:10.1071/EN05078, 2005.

Pechtl, S., Lovejoy, E. R., Burkholder, J. B., and von Glasow, R.: Modeling the possible role of iodine oxides in atmospheric new particle formation, Atmos. Chem. Phys., 6, 505-523, 2006, http://www.atmos-chem-phys.net/6/505/2006/.

Peters, C., Pechtl, S., Stutz, J., Hebestreit, K., Hönninger, G., Heumann, K. G., Schwarz, A., Winterlik, J., and Platt, U.: Reactive and organic halogen species in three different European coastal environments, Atmos. Chem. Phys., 5, 3357-3375, 2005, http://www.atmos-chem-phys.net/5/3357/2005/.

Platt, U. and Hönninger, G.: The role of halogen species in the troposphere, Chemosphere, 52, 325-338, 2003.

Platt, U. and Perner, D.: Measurements of Atmospheric Trace Gases by Long Path Differential UV/visible Absorption Spectroscopy, in: Optical and Laser Remote Sensing, edited by: Killinger, D. K. and Mooradian, A., 95-105, Springer Verlag, New York, 1983.

Platt, U. and Stutz, J.: Differential Optical Absorption Spectroscopy, Physics of Earth and Space Environments. ISBN 978- 
3-540-21193-8. Springer-Verlag Berlin Heidelberg, 2008.

Read, K. A., Mahajan, A. S., Carpenter, L. J., Evans, M. J., Faria, B. V. E., Heard, D. E., Hopkins, J. R., Lee, J. D., Moller, S. J., Lewis, A., Mendes, L., McQuaid, J. B., Oetjen, H., Saiz-Lopez, A., Pilling, M. J., and Plane, J. M. C.: Extensive halogenmediated ozone destruction over the tropial Atlantic Ocean, Nature, 453, 1232-1235, doi:10.1038/nature07 035, 2008.

Rothman, L. S., Jacquemart, D., Barbe, A., Benner, D., Birk, M., Brown, L. R., Carleer, M. R. C. C. J., Chance, K., Coudert, L. H., Dana, V., Devi, V. M., Flaud, J.-M., Gamache, R. R., Goldman, R., A., Hartmann, J.-M., Jucks, K. W., Maki, A. G., Mandin, J.Y., Massie, S. T., Orphal, J., Perrin, A., Rinsland, C. P., Smith, M. A. H., Tennyson, J., Tolchenov, R. N., Toth, R., Auwera, J. V., Varanasi, P., and Wagner, G.: The HITRAN 2004 Molecular Spectroscopic Database, J. Quant. Spectrosc Rad. Transf., 96, 139-204, 2005.

Saiz-Lopez, A. and Plane, J. M. C.: Novel iodine chemistry in the marine boundary layer, Geophys. Res. Lett., 31, L04112, doi:10.1029/2003GL019215, 2004a.

Saiz-Lopez, A. and Plane, J. M. C.: Novel iodine chemistry in the marine boundary layer, Geophys. Res. Lett., 31, L04112, doi:10.1029/2003GL019215, 2004b.

Saiz-Lopez, A., Plane, J. M. C., and Shillito, J. A.: Bromine oxide in the mid-latitude marine boundary layer, Geophys. Res. Lett., 31, L03111, doi:10.1029/2003GL018956, 2004a.

Saiz-Lopez, A., Saunders, R. W., Joseph, D. M., Ashworth, S. H., and Plane, J. M. C.: Absolute absorption cross-section and photolysis rate of $\mathrm{I}_{2}$, Atmos. Chem. Phys., 4, 1443-1450, 2004b, http://www.atmos-chem-phys.net/4/1443/2004/.

Saiz-Lopez, A., Plane, J. M. C., McFiggans, G., Williams, P. I., Ball, S. M., Bitter, M., Jones, R. L., Hongwei, C., and Hoffmann, T.: Modelling molecular iodine emissions in a coastal marine environment: the link to new particle formation, Atmos. Chem. Phys., 6, 883-895, 2006a,

http://www.atmos-chem-phys.net/6/883/2006/.

Saiz-Lopez, A., Shillito, J. A., Coe, H., and Plane, J. M. C.: Measurements and modelling of $\mathrm{I} 2, \mathrm{IO}, \mathrm{OIO}, \mathrm{BrO}$ and $\mathrm{NO} 3$ in the mid-latitude marine boundary layer, Atmos. Chem. Phys., 6, 1513-1528, 2006b,

http://www.atmos-chem-phys.net/6/1513/2006/.

Saiz-Lopez, A., Plane, J. M. C., Mahajan, A. S., Anderson, P. S., Bauguitte, S. J.-B., Jones, A. E., Roscoe, H. K., Salmon, R. A., Bloss, W. J., Lee, J. D., and Heard, D. E.: On the vertical distribution of boundary layer halogens over coastal Antarctica: implications for $\mathrm{O}_{3}, \mathrm{HO}_{\mathrm{x}}, \mathrm{NO}_{\mathrm{x}}$ and the $\mathrm{Hg}$ lifetime, Atmos. Chem. Phys., 8, 887-900, 2008,

http://www.atmos-chem-phys.net/8/887/2008/.

Schönhardt, A., Richter, A., Wittrock, F., Kirk, H., Oetjen, H., Roscoe, H. K., and Burrows, J. P.: Observations of iodine monoxide columns from satellite, Atmos. Chem. Phys., 8, 637653, 2008,

http://www.atmos-chem-phys.net/8/637/2008/.

Seinfeld, J. and Pandis, S.: Atmospheric chemistry and physics, New York, 1998.
Sellegri, K., Yoon, Y. J., Jennings, S. G., O’Dowd, C. D., Pirjola, L., Cautenet, S., Chen, H., and Hoffmann, T.: Quantification of Coastal New Ultra-Fine Particles Formation from In situ and Chamber Measurements during the BIOFLUX Campaign, 2, 260-270, 2005.

Simpson, W. R., Carlson, D., Hönninger, G., Douglas, T. A., Sturm, M., Perovich, D., and Platt, U.: First-year sea-ice contact predicts bromine monoxide $(\mathrm{BrO})$ levels at Barrow, Alaska better than potential frost flower contact, Atmos. Chem. Phys., 7, 621-627, 2007 , http://www.atmos-chem-phys.net/7/621/2007/.

Spietz, P., Martin, J., and Burrows, J. P.: Spectroscopic studies of the $\mathrm{I}_{2} / \mathrm{O}_{3}$ photochemistry. Part 2. Improved spectra of iodine oxides and analysis of the IO absorption spectrum, J. Photochem. Photobiol. A: Chem., 176, 50-67, 2005.

Stutz, J. and Platt, U.: Numerical Analysis and Estimation of the Statistical Error of Differential Optical Absorption Spectroscopy Measurements with Least-Squares methods, Appl. Optics, 35, 6041-6053, 1996.

Stutz, J. and Platt, U.: Improving longpath differential optical absorption spectroscopy with a quartz-fiber mode mixer, Appl. Optics, 36, 1105-1115, 1997.

Stutz, J., Pikelnaya, O., Hurlock, S. C., Trick, S., Pechtl, S., and von Glasow, R.: Daytime OIO in the Gulf of Maine, Geophys. Res. Lett., 34, L22816, doi: 10.1029/2007GL031332, 2007.

Vandaele, A., Hermans, C., Simon, P., Carleer, M., Colin, R., Fally, S., Merienne, M., Jenouvrier, A., and Coquart, B.: Measurements of the $\mathrm{NO}_{2}$ absorption cross-section from $42000 \mathrm{~cm}^{-1}$ to $10000 \mathrm{~cm}^{-1}(238-1000 \mathrm{~nm})$ at $220 \mathrm{~K}$ and $294 \mathrm{~K}$, J. Quant. Spectrosc. Rad. Transfer, 59, 171-184, 1998.

Voigt, S., Orphal, J., Bogumil, K., and Burrows, J. P.: The temperature dependence (203-293 K) of the absorption cross sections of $\mathrm{O}_{3}$ in the $230-850 \mathrm{~nm}$ region measured by Fourier-transform spectroscopy, J. Photochem. Photobiol., 143, 1-9, 2001.

Voigt, S., Orphal, J., and Burrows, J. P.: The temperature and pressure dependence of the absorption cross-sections of $\mathrm{NO}_{2}$ in the $250-800 \mathrm{~nm}$ region measured by Fourier-transform spectroscopy, J. Photochem. Photobiol., 149, 1-7, 2002.

von Glasow, R. and Crutzen, P.: Tropospheric halogen chemistry, edited by: Holland, H. D. and Turekian, K. K., Treatise on Geochemistry Update 1, 4.02, 1-67, 2007.

Vuollekoski, H., Kerminen, V.-M., Anttila, T., Sihto, S.-L., Vana, M., Ehn, M., Korhonen, H., McFiggans, G., O’Dowd, C., and Kulmala, M.: Iodine dioxide nucleation simulations in coastal and remote marine environments, J. Geophys. Res., 114, D02206, doi:10.1029/2008JD010713, 2009.

Wang, S. and Flagan, R.: Scanning electrical mobility spectrometer, Aerosol Sci. Technol., 13, 230-240, 1990.

Wilmouth, D. M., Hanisco, T. F., Donahue, N. M., and Anderson, J. G.: Fourier transform ultraviolet spectroscopy of the $A^{2} \Pi_{3 / 2} \leftarrow X^{2} \Pi_{3 / 2}$ transition of BrO, J. Phys. Chem., 103, 8935-8945, 1999. 